\title{
Medisinsk fødselsregister som utgangspunkt for livsløpsstudier
}

\author{
Petter Kristensen \\ Avdeling for arbeidsmedisin og epidemiologi, Statens arbeidsmiljøinstitutt, Oslo og \\ Seksjon for forebyggende medisin og epidemiologi, Universitetet i Oslo \\ E-post: petter.kristensen@stami.no
}

\begin{abstract}
SAMMENDRAG
Grunnlaget for helse og funksjon i voksen alder legges gjennom hele livsløpet. Medisinsk fødselsregister (MFR) er det naturlige utgangspunktet for populasjonsbaserte livsløpsstudier i Norge. I denne oversikten gis eksempler på studier hvor MFR-data er koblet mot andre datakilder med oppfølging opp til ung voksen alder. Styrken til MFR ligger på flere områder. For det første er det mulig å etablere kohorter av alle som er født i Norge siden 1967. For det andre har MFR rikholdige data av nytte i livsløpsstudier. For det tredje gir MFR mulighet for å etablere søskenkohorter, noe som kan vise seg å være av stor verdi i denne typen studier. I prinsippet kan fødte i MFR følges gjennom 40 år i dag (2007).
\end{abstract}

\section{Kristensen P. The Medical Birth Registry of Norway as a starting point for population based life course epidemiology. Nor J Epidemiol 2007; 17 (2): 147-152.}

\section{ENGLISH SUMMARY}

Health and functional capacity in adult age are founded on experiences during the whole life course. The Medical Birth Registry of Norway (MBRN) is the natural starting-point for population based life course epidemiology in Norway. In this outline, examples of life course studies are provided, combining data from MBRN and other sources. Such linkage is possible in Norway, due to the registers' use of the unique national identification number assigned to all national residents. MBRN has several advantages. First, it is feasible to establish complete cohorts of all who were born in Norway since 1967. Second, the MBRN contains a multitude of data of interest. Third, the establishment of sibship files is possible in MBRN. MBRN contains births from 1967 onwards, and 40 years of follow up is in principle possible to-day.

\section{INNLEDNING}

En av markeringene ved 30-årsjubileet til Medisinsk fødselsregister (MFR) var et spesialnummer av Acta Obstetricia et Gynecologica Scandinavica (1). Lorentz M. Irgens ga her følgende oppsummering av Fødselsregisterets fremtidige utfordringer: "With an extended longitudinal epidemiological perspective, the concept of perinatal risk factors for adult cardiovascular diseases and cancer has evolved. In a few years, the MBRN will provide a basis for the assessment of such associations" (2).

Stikkord for denne oppsummeringen var lanseringen av den såkalte Barker-hypotesen tidlig på 1990tallet (3). Den har senere fått navnet "fetal origins" eller "programming" hypotesen. Den gikk ut på at individer som var utsatt for sparsommelige vekstforhold i svangerskapet med blant annet lav fødselsvekt til følge ("thrifty phenotype") ville tåle forholdene i overflodssamfunnet dårlig og få økt risiko for diabetes og andre kroniske sykdommer i voksenlivet. Forsdahl hadde vært inne på lignende ideer 20 år tidligere (4). I kjølvannet av denne hypotesen ble begrepet livsløpsepidemiologi (5) lansert: Ideen var at forhold i svangerskap og ved fødsel ikke var de eneste som spilte rolle for helse og kronisk sykdom i voksen alder: Dette ble påvirket av forhold opp gjennom hele livsløpet, enten i tillegg til eller i samspill med forhold i svangerskapet.

Det er betegnende at merkelappene programmeringshypotese eller livsløpsepidemiologi ikke passet til noen av originalbidragene til 30-årsjubileet (1). Noen få år senere kom Norsk Epidemiologis temanummer, "Tidlig eksponering og senere sykdom" (6). Her var situasjonen endret: Flertallet av originalbidragene i temanummeret tok utgangspunkt i populasjoner basert på MFR. Dette er en klar indikasjon på at den utviklingen Irgens forventet er i full gang.

Hensikten med dette bidraget til jubileet er å gi en oversikt over bruken av MFR og å gi uttrykk for min mening om brukbarheten av MFR i livsløpsstudier. Jeg tar utgangspunkt $i$ et perspektiv "fra vuggen til graven". Jeg vil derfor ikke omtale longitudinelle studier av langsiktige helseeffekters relasjon til foreldreskap, for eksempel risiko for hjertekarsykdom eller kreft etter svangerskap med pre-eklampsi $(7,8)$. Jeg vil avgrense meg til studier med oppfølging til voksen alder, vel vitende om at det er mange verdifulle studier av pre- og perinatale faktorer og senere sykdom i barnealderen. Allerede i 1985 publiserte Gayle Windham, Tor Bjerkedal og Frøydis Langmark en studie av kreft- 
insidens i barnealder blant tvillinger og barn med medfødte misdannelser og lav fødselsvekt (9). Senere studier av helseeffekter i barnealder inkluderer kreft (10-12) og diabetes (13-17), se for øvrig egne artikler om MFR og henholdsvis kreft (18) og diabetes (19) i dette nummeret.

Norsk Epidemiologi har dekket dette emneområdet grundig og mange av referansene vil finnes i fullformat på tidsskriftets hjemmeside http:/www.ub. ntnu.no/journals/norepid/issues.html.

\section{EKSEMPLER PÅ BRUK AV MFR I STUDIER MED LANGVARIG OPPFØLGING FRA FØDSELEN}

I det følgende vil eksempler på koblinger mellom MFR og ulike registre kort beskrives. Utfallene som studeres vil være avhenge av hvilke registre som inngår. Flere av kildene har i tillegg en del basisdata, så som vital status. Totalmortalitet har derfor vært et ekstra endepunkt i flere av studiene som refereres her.

\section{Sesjonsdata}

Vernepliktsverket inneholder data på helse og funksjon for unge menn fra sesjonsundersøkelser gjennom mer enn femti år. Verneplikt har vært obligatorisk for norske menn, og dette innebærer at man har kunnet gjennomføre populasjonsbaserte studier hvor omtrent $90 \%$ av den mannlige befolkningen bidrar med data. Data som inngår er blant annet intellektuell funksjon, høyde og vekt, samt vurdering av fysisk kapasitet, sansefunksjoner og mental funksjon. Selv om gruppen av menn som ikke stiller til sesjon er sterkt selektert utgjør denne datakilden et godt utgangspunkt for å studere funksjon og helse i ung voksen alder.

Sammenhengen mellom perinatale forhold og BMI og evnenivå ved sesjon blant nesten 400000 guttebarn født 1967-1979 inngikk i doktoravhandlingen til Martha Gunn Eide (20). Resultatene er også publisert tidligere i Norsk Epidemiologi (21). Studien viste at det var positiv assosiasjon mellom størrelse ved fødsel og størrelse (BMI, kroppslengde) ved sesjon (22). Evnenivå ved sesjon ble videre sammenlignet for menn som hadde vært født i seteleie respektive hodeleie uten at det ble funnet forskjeller (23). Det var heller ikke klare assosiasjoner mellom kategorier av medfødte misdannelser og evnenivå målt ved sesjon, med unntak av noen få kategorier av alvorlige misdannelser (24). I en studie av norske menn født i 19671971 var det en moderat men konsistent positiv assosiasjon mellom fødselsvekt og evnenivå ved sesjon (25). Studiet av sammenheng mellom mors helse og sønnenes senere sesjonsresultater er en annen mulighet med bruk av MFR-data. Øyen og medarbeidere fant at epilepsi hos mor var assosiert med lavt evnenivå og lav kroppshøyde hos sønnene (26).

En noe annen bruk av MFR-data er utnyttet i studiet av relasjonen mellom paritet og evnenivå. MFR ble brukt som utgangspunkt for å etablere en kohort basert på søskenflokker til mødre med første fødsel i 1967-1976. i denne kohorten inngikk en kvart million sønner med senere sesjonsdata. På denne måten kunne evnenivå sammenlignes mellom brødre i en kohort med mor (søskenflokken) som observasjonsenhet (27). Den morsbaserte kohorten gjorde det også mulig å identifisere eldre søsken som var dødfødte eller døde $\mathrm{i}$ spedbarnsalder, og på den måten finne ut om det var biologisk rang (paritet) eller sosial rang i familien som var assosiert med evnenivå ved sesjon (28).

\section{Kreftregisteret}

Helt siden studien til Windham og medarbeidere i 1985 (9) har det vært knyttet forventninger til studier av perinatale faktorer og senere kreftrisiko gjennom kobling mellom MFR og Kreftregisteret. Dette temaet blir drøftet av Tretli og medarbeidere i dette nummeret av Norsk Epidemiologi (18). Til nå er det naturlig nok bare få eksempler på studier av kreft i voksen alder, og disse gjelder i første rekke testikkelkreft. Insidensen av testikkelkreft er forholdsvis høy i ung voksen alder, så allerede i 1998 publiserte Eva Wanderås og medarbeidere en studie som viste at mors helse i svangerskapet, placentaforhold og paritet påvirket insidensen av testikkelkreft (29). I en senere studie (30) ble flere av assosiasjonene bekreftet, og materialet var også så robust at man kunne påvise indikasjoner på heterogenitet mellom ulike undergrupper av testikkelkreft.

\section{Registre i NAV}

Det klareste eksemplet til nå på en kohort med utgangspunkt i MFR og med livsløpshistorier fra flere registerkilder er etablert av Tor Bjerkedal. Alle levendefødte i MFR 1967-1976 ( $\mathrm{N}=626$ 928) er utgangspunktet. Til dette er det koblet data fra Vernepliktsverket (sesjonsdata), NAV (registrene over pensjonsgivende inntekt, stønad, pensjonsytelser og sykefravær), SSB (utdanningsregisteret), samt det Sentrale personregister for indekspersonene og deres foreldre. På denne måten er det etablert historier over sosial posisjon og funksjon og enkelte helseforhold opp gjennom livsløpet. Hovedhensikten med dette prosjektet har vært å studere forhold som påvirker deltakelse (innpass, utstøting) i arbeidslivet. Her studeres sosiale ulikheter i helse, og spesielt de seleksjonsfaktorene som bestemmer sosial posisjon i voksen alder.

MFR er et viktig utgangspunkt for selve etableringen av kohorten. I tillegg har data i MFR blitt benyttet for å studere utfall assosiert med perinatale forhold. Et eksempel er studien av faktorer opp gjennom livsløpet og deres assosiasjon med deltakelse i arbeidslivet: Fødselsvekt var negativt assosiert med senere arbeidsdeltakelse, det samme gjaldt helseforhold i barnealder (innbefattet medfødte misdannelser og fødselsskader) (31). Evnenivå ved sesjon synes å være en mellomliggende variabel som forklarer det meste av assosiasjonen mellom fødselsvekt og arbeidsdeltakelse hos menn (25). Relasjonen mellom fødselsvekt og senere 
uførepensjon (32) og muskelskjelettsykefravær (33) er eksempler på studier av andre utfall. Gjennomgående synes det som om perinatale forhold spiller mindre rolle for senere sosial funksjon sammenlignet med sosiale oppvekstvilkår. Det er imidlertid klare unntak; eksempelvis den sosiale prognosen i voksen alder ved Down syndrom (34). Også andre MFR-data har vært brukt, eksempelvis barnetall hos menn og kvinner i kohorten for å belyse kjønnsforskjeller i barnetallets betydning for utdanning og yrkesaktivitet (35).

NAV-registre har også vært koblet med MFR i andre studier. Alle levendefødte i MFR 1967-1993 har vært fulgt opp i pensjonsregisteret med registrering av grunn- og/eller hjelpestønad ut 1996, hvilket vil si at de eldste ble fulgt til 29 års alder (36,37). Risikoen for stønad med astmadiagnose var assosiert med forhold registrert i MFR, blant annet mors helse (atopi, nedre luftveisinfeksjon i svangerskapet) og ulike svangerskapskomplikasjoner (36). Stønad på grunn av nedsatt hørsel var sterkt assosiert med maternell virussykdom med eksantem i svangerskapet, og jo lavere fødselsvekten var, jo høyere var sannsynligheten for stønad (37). I studien av medfødte misdannelser og senere sesjonsresultater (24) ble også uførepensjon ved alder 18 år registrert: Forekomsten varierte sterkt med misdannelseskategori, fra et nivå som var likt med unge menn uten medfødt misdannelse (leppespalte) til nær $100 \%$ (Down syndrom).

\section{Forskningsregistre ved Nasjonalt folkehelseinstitutt}

Folkehelseinstituttet er ansvarlig for flere registre som vil være helt sentrale i livsløpsstudier. Det mest nærliggende er COhort NORway (CONOR) og de regionale helseundersøkelsene som inngår i denne kohorten. Til nå er det få eksempler på kobling mellom MFR og CONOR som ledd i livsløpsstudier. En forklaring på dette er at andelen deltakere født etter 1966 er forholdsvis lav (38).

I Helseundersøkelsen i Nord-Trøndelag (UngHUNT) er det etablert en kohort av knappe 5000 jenter som deltok mellom 1995 og 1997, og som er koblet opp mot MFR. Utfallene som ble registrert var basert på kliniske undersøkelser og spørreskjemaopplysninger i alderen 13-19 år. I en studie er relasjonene mellom mål på størrelse ved fødsel, alder for menarke, og høyde/vekt i ungdomsalder analysert (39). Også betydningen av eksponering for pre-eklampsi før fødsel på alder for menarke, samt høyde/vekt og blodtrykk i ungdomsalder er studert (40). Disse studiene kan peke frem mot senere livsløpsstudier med arteriell hypertensjon i voksen alder og brystkreft som endepunkter.

\section{Generasjonsstudier i MFR}

Rolv Skjærven leder et generasjonsprosjekt i MFR. Her studeres data for reproduksjon og fødsel over to generasjoner. Et viktig formål med disse generasjonsstudiene er å nøste opp ulike genetiske komponenters bidrag til risiko for gjentakelse av studerte endepunk- ter (41-43). Men de kan også tjene andre hensikter, inkludert studier av programmeringshypotesen og livsløpets betydning.

Klare eksempler på det siste er Egeland og medarbeideres studie av sammenhengene mellom perinatale faktorer og senere utvikling av gestasjonsdiabetes (44), og studiet av langtidsvirkninger blant døtre av diabetiske mødre (45). Risikoen for å få gestasjonsdiabetes var økt når mor til den fødende også hadde hatt diabetes i svangerskapet, i tillegg var lav fødselsvekt en risikofaktor (44). Kvinner som hadde vært prenatalt eksponert for mors diabetes hadde en økt risiko for å få dødfødte barn når de selv ble gravide (45). Et annet eksempel på togenerasjonsstudier hvor barn med medfødte misdannelser er fulgt til voksen alder viser ikke bare en økt risiko for gjentakelse (som var sterkere for menn enn kvinner), men også sosiale konsekvenser (sannsynlighet for selv å få barn) som var sterkt avhengig av misdannelseskategori (46-48).

\section{HVA KAN MFR BIDRA MED?}

I temanummeret "Tidlig eksponering og senere sykdom" ble det hevdet redaksjonelt at MFR er en naturlig basis for norsk livsløpsepidemiologisk forskning (6). Det er faktisk flere forhold som underbygger dette standpunktet. Rent praktisk vil ad hoc-baserte alternativer til MFR være langt mer arbeidskrevende. Vi har noen eksempler på etablering av kohorter som et alternativt design i tiden før det lot seg gjøre å etablere MFR-baserte kohorter som kunne følges over tilstrekkelig lang tid. Et eksempel på dette er tidligere studier av forløsningsmetode og senere evnenivå ved sesjon: Muligheten for å etablere populasjoner av fødte tidlig på 1960-tallet var sterkt begrenset hvilket medførte usikre estimater på sammenheng $(49,50)$. En gjentakelse av studien når tiden var moden for etablering av en MFR-basert kohort (23) ga en populasjon av en helt annen størrelsesorden. Det finnes også eksempler på etablering av ad-hoc-baserte studiepopulasjoner på områder hvor tiden fortsatt ikke er moden for bruk av MFR. Dette gjelder livsløpsstudier av brystkreft og prostatakreft. Man kan lett tenke seg at en formidabel innsats var påkrevet fra Institutt for samfunnsmedisin ved NTNU som ligger bak etableringen av en kohort på 35000 kvinner og menn som ble født på EC Dahls Stiftelse mellom 1920 og 1958, for på den måten å studere perinatale risikofaktorer for brystkreft (51) og prostatakreft (52).

Et godt argument for å bruke MFR er at man får et populasjonsbasert utgangspunkt av alle fødte i Norge. Ved rene registerkoblinger mot andre nasjonale registre vil frafallet være lite: Av de levendefødte i 1967kullet i MFR var 3,6\% døde og 3,0\% emigrerte ved utløpet av 2003.

For mange vil variablene i MFR knyttet til den enkelte fødte i fødselsmeldingen være det som først og fremst frister. Her er unektelig mulighetene mange: 
Ulike mål på størrelse ved fødsel og svangerskapsvarighet er sentrale for hypoteser om årsaker til hjertekarsykdom, diabetes 2 og viktige kreftformer. Flere forhold knyttet til fødselsforløpet kan være av betydning, videre medfødte misdannelser, mors helse før og under svangerskapet, placentaforhold o.a.

En viktig styrke ved MFR er muligheten for å etablere søskenbaserte kohorter. Betydningen av å ta hensyn til familiekarakteristika er grundig dokumentert med MFR-data, blant annet ved doktorarbeidene til Rolv Skjærven (53) og senere Kari Klungsøyr Melve (54). Se også deres bidrag om selektiv fertilitet i dette nummeret (55). Skjærven og medarbeidere viste at sammenhengen mellom fødselsvekt og perinatal mortalitet er sterkt betinget av fødselsvekten til eldre søsken, eller sagt med andre ord, hvor normal eller unormal egen fødselsvekt var i forhold til andre i familien (56). Kanskje det samme gjelder helse og risiko for sykdom og død senere i livet? I så tilfelle kunne forfølging av programmeringshypotesen være mer vellykket om målene for den enkelte fødte ble relatert til en familienorm. Søskenbaserte kohorter kan derfor være viktige også i livsløpsepidemiologi. Dette er et argument for å bruke MFR som utgangspunkt for kohortetablering. I prinsippet kunne familiebaserte analysefiler også etableres på basis av SSB-data, men man ville da være begrenset til søskenflokker av levendefødte. En slik begrensning ville for eksempel ikke gjøre det mulig å studere paritet og evnenivå betinget av vital status til eldre søsken (28).

\section{HVILKE STUDIER KAN VI FORVENTE I DE N/ERMESTE ÅRENE?}

Begrensningene for fremtidige studier ligger $\mathrm{i}$ aldersfordelingen av registrert fødte i MFR, og av hvilke registre og andre kilder som er tilgjengelige for kobling. Betingelsene for kobling mot en lang rekke helseregistre (57) er gode. Det er viktig å avklare hvor omfattende koblinger som er nødvendige for å gjennomføre livsløpsstudier. Flere av de eksemplene jeg har gitt her er basert på MFR-data og ett senere endepunkt, men bare få opplysninger om den mellomliggende perioden mellom fødsel og utfallet. Livsløpsepidemiologi som konsept (5) bygger på hypoteser om at ulike livsfaser har betydning, og bruk av data fra flere kilder og tidsavsnitt er også en mulighet vi har i Norge.

Det finnes muligheter i dag for å studere betydningen av MFR-data og andre livsløpsfaktorer for blant annet psykiatrisk helse i ung voksen alder: Psykiatrisk uførhet registrert i NAV og årsaksspesifikk dødelighet (suicid) er mulige studieområder. Den norske mor og barn-undersøkelsen (MoBa) inneholder også MFRdata, og man kan utnytte denne kohorten i dag med foreldres MFR-data som determinanter og ulike data fra MoBa som kovariater og endepunkter. Mulighetene for å utnytte MFR-data til videre studier av diabetes og BMI i voksen alder blir bedre dag for dag. Selv om Irgens' forhåpninger ved 30-årsjubileet (2) ikke er realisert står vi i startgropen for å bruke MFR i livsløpsstudier av hjertekarsykdom og kreft.

\section{REFERANSER}

1. Bergsjø P, Irgens LM, Lie RT, red. Special issue: The Norwegian Medical Birth Registry. Thirty years of population-based registration. Acta Obstet Gynecol Scand 2000; 79 (6): 433-522.

2. Irgens LM. The Medical Birth Registry of Norway. Epidemiological research and surveillance throughout 30 years. Acta Obstet Gynecol Scand 2000; 79 (6): 435-439.

3. Barker DJ. Mothers, babies and disease in later life. London: BMJ Publishing Group, 1994.

4. Forsdahl A. Are poor living conditions in childhood and adolescence an important risk factor for arteriosclerotic heart disease? Br J Prev Soc Med 1977; 31 (2): 91-95 (opptrykt i Norsk Epidemiologi 2005; 15 (1): 5-9.

5. Kuh D, Ben-Shlomo Y, red. A life course approach to chronic disease epidemiology. Second edition. Oxford: Oxford University Press, 2002.

6. Irgens LM, Kristensen P, Vatten LJ, red. Tidlig eksponering og senere sykdom. Norsk Epidemiologi 2005; 15 (1): 3-98.

7. Irgens HU, Reisæther L, Irgens LM, Lie RT. Long term mortality of mothers and fathers after pre-eclampsia: population based cohort study. BMJ 2001; 323; 1213-17.

8. Vatten LJ, Romundstad PR, Trichopoulos D, Skjærven R. Pre-eclampsia in pregnancy and subsequent risk for breast cancer. Br J Cancer 2002; 87: 971-3.

9. Windham G, Bjerkedal T, Langmark F. A population-based study of cancer incidence in twins and in children with congenital malformations or low birth weight, Norway, 1967-1980. Am J Epidemiol 1985; 121: 49-56.

10. Heuch JM, Heuch I, Kvale G. Birth characteristics and risk of Wilm's tumour: a nationwide prospective study in Norway. Br J Cancer 1996; 74: 1148-1151.

11. Heuch JM, Heuch I, Akslen LA, Kvale G. Risk of primary childhood brain tumors related to birth characteristics: a Norwegian prospective study. Int J Cancer 1998; 77: 498-503.

12. Samuelsen SO, Bakketeig LS, Tretli S, Johannesen TB, Magnus P. Head circumference at birth and risk of brain cancer in childhood: a population-based study. Lancet Oncol 2006; 7: 39-42. 
13. Stene LC, Magnus P, Lie RT, Søvik O, Joner G, the Norwegian Childhood Diabetes Study Group. Birth weight and childhood onset onset type 1 diabetes: population based cohort study. BMJ 2001; 322: 889-892.

14. Stene LC, Magnus P, Lie RT, Søvik O, Joner G, the Norwegian Childhood Diabetes Study Group. Maternal and paternal age at delivery, birth order, and risk of childhood onset type 1 diabetes: population based cohort study. BMJ 2001; 323: 369-371.

15. Stene LC, Magnus P, Lie RT, Søvik O, Joner G, the Norwegian Childhood Diabetes Study Group. No association between pre-eclampsia or caesarean section and the incidence of type 1 diabetes: a large population based cohort study. Pediat Res 2003; 54: 487-490.

16. Stene LC, Magnus P, Rønningen KS, Joner G. Diabetes-associated HLA-DQ genes and birth weight. Diabetes 2001; 50: 2879-2882.

17. Stene LC, Thorsby PM, Berg JP, Rønningen KS, Undlien DE, Joner G, et al. The relation between size at birth and risk of type 1 diabetes is not influenced by adjustment for the insulin gene $(-23 \mathrm{HphI})$ polymorphism or HLA-DQ genotype. Diabetologia 2006; 49: 2068-2073.

18. Tretli S, Grotmol T, Langmark F. Er det forskningsmessig interessant å koble data fra Medisinsk fødselsregister med data fra Kreftregisteret? Norsk Epidemiologi 2007; 17 (2): 111-114.

19. Stene LC, Eidem I, Vangen S, Joner G, Irgens LM, Moe N. The validity of the diabetes mellitus diagnosis in the Medical Birth Registry of Norway. Norsk Epidemiologi 2007; 17 (2): 165-174.

20. Eide MG. Associations of perinatal conditions with adult body size and intelligence: a register-based cohort study in Norway 1967-1999. Avhandling. Bergen: Universitetet i Bergen, 2005.

21. Eide MG. Influences of perinatal conditions on adult body size and intellectual performance: a register-based cohort study. Norsk Epidemiologi 2005; 15 (1): 29-40.

22. Eide MG, Øyen N, Skjærven R, Nilsen ST, Bjerkedal T, Tell GS. Size at birth and gestational age as predictors of adult height and weight. Epidemiology. 2005; 16: 175-181.

23. Eide MG, Øyen N, Skjærven R, Irgens LM, Bjerkedal T, Nilsen ST. Breech delivery and intelligence: a population-based study of 8,738 breech infants. Obstet Gynecol 2005; 105: 4-11.

24. Eide MG, Skjærven R, Irgens LM, Bjerkedal T, Øyen N. Associations of birth defects with adult intellectual performance, disability and mortality: population-based cohort study. Pediat Res 2006; 59: 848-853.

25. Kristensen P, Bjerkedal T, Irgens LM, Gravseth HM, Brevik JI, Impact of life course determinants on work participation among young Norwegian men. Norsk Epidemiologi 2005; 15 (1): 65-74.

26. Øyen N, Vollset SE, Eide MG, Bjerkedal T, Skjærven R. Maternal epilepsy and offsprings' adult intelligence: a population-based study from Norway. Epilepsia 2007; 48: 1731-1738.

27. Bjerkedal T, Kristensen P, Skjeret GA, Brevik JI. Intelligence test scores and birth order among young Norwegian men (conscripts) analyzed within and between families. Intelligence 2007; 35: 503-514.

28. Kristensen P, Bjerkedal T. Explaining the relation between intelligence and birth order. Science 2007; 316: 1717 + http: //www.sciencemag.org/cgi/content/full/316/5832/1717/DC1.

29. Wanderås EH, Grotmol T, Fosså SD, Tretli S. Maternal health and pre- and perinatal charateristics in the etiology of testicular cancer: a prospective population- and register-based study on Norwegian males born between 1967 and 1995. Cancer Causes Control 1998; 9 (5): 475-486.

30. Aschim EL, Haugen TB, Tretli S, Daltveit AK, Grotmol T. Risk factors for testicular cancer - differences between pure non-seminoma and mixed seminoma/non-seminoma? Int J Androl 2006; 29: 458-467.

31. Kristensen P, Bjerkedal T, Irgens LM. Birthweight and work participation in adulthood. Int J Epidemiol 2004; 33: 849-856.

32. Gravseth HM, Kristensen P, Aalen OO, Selmer R, Bjerkedal T, Irgens LM. Life course determinants for early disability pension. Eur J Epidemiol 2007; 22: 533-543.

33. Kristensen P, Bjerkedal T, Irgens LM. Early life determinants of musculoskeletal sickness absence in a cohort of Norwegians born in 1967-1976. Soc Sci Med 2007; 64: 646-655.

34. Bjerkedal T, Kristensen P. Levendefødte i Norge 1967-76 med diagnosen Down syndrom - en registerstudie. Norsk Epidemiologi 2007; 17 (2): 157-164.

35. Bjerkedal T, Kristensen P. Barnetallets betydning for utdanning og yrkesaktivitet: En analyse av kvinner og menn født i Norge i 1967-71 fulgt opp til fylte 30 år. I: Leira HL, red. Ingen kommer undan politiken. Festskrift til Ebba Wergeland på sekstiårsdagen. Trondheim: Transit, 2006: 57-69.

36. Nafstad P, Samuelsen SO, Irgens LM, Bjerkedal T. Svangerskapskomplikasjoner og risikoen for astma blant nordmenn født 1967-1993. Norsk Epidemiologi 2005; 15 (1): 47-54 (Basert på Nafstad P, Samuelsen SO, Irgens LM, Bjerkedal T. Pregnancy complications and the risk of asthma among Norwegians born between 1967 and 1993. Eur J Epidemiol 2003; 18: 755-761).

37. Nafstad P, Samuelsen SO, Irgens LM, Bjerkedal T. Birth weight and hearing impairment in Norwegians born from 1967 to 1993. Pediatrics 2002; 110 (3): e30.

38. Engeland A, Søgaard AJ. CONOR (Cohort NORway) - en oversikt over en unik forskningsdatabank. Norsk Epidemiologi 2003; 13 (1): 73-77. 
39. Romundstad PR, Vatten LJ, Mæhle BO, Lund Nilsen TI, Tretli S, Hsieh C-C, Trichopoulos D, Stuver SO. Birth size in relation to age at menarche and adolescent body size: implications for breast cancer. Int J Cancer 2003; 105: 400-403.

40. Vatten LJ, Romundstad PR, Holmen TL, Hsieh C-C, Trichopoulos D, Stuver SO. Intrauterine exposure to preeclampsia and adolescent blood pressure, body size, and age at menarche in female offspring. Obstet Gynecol 2003: 101: 529-533.

41. Lie RT. Intergenerational exchange and perinatal risks: a note on interpretation of generational recurrence risks. Paediat Perinat Epidemiol 2007; 21 (suppl 1): 13-18.

42. Lunde A, Melve KK, Gjessing HK, Skjærven R, Irgens LM. Genetic and environmental influences on birth weight, head circumference, and gestational age by use of population-based parent-offspring data. Am $J$ Epidemiol 2007; 165: 734-741.

43. Skjærven R, Vatten LJ, Wilcox AJ, Rønning T, Irgens LM, Lie RT. Recurrence of pre-eclampsia across generations: exploring fetal and maternal genetic components in a population-based cohort. BMJ 2005; 331: 877-879.

44. Egeland GM, Skjærven R, Irgens LM. Birth characteristics of women who develop gestational diabetes. $B M J$ 2000; 321: 546-547.

45. Egeland GM, Skjærven R, Irgens LM. The reproductive health of daughters of pregestational diabetic women: Medical Birth Registry of Norway. Paediat Perinat Epidemiol 2002; 16: 290-296.

46. Lie RT, Skjærven R, Follow-up studies of children with birth defects in the Medical Birth Registry of Norway: A review. Norsk Epidemiologi 2005; 15 (1): 21-24.

47. Skjærven R, Wilcox AJ, Lie RT. A population-based study of survival and childbearing among female subjects with birth defects and the risk of recurrence in their children. N Eng J Med 1999; 340: 1057-62.

48. Lie RT, Wilcox AJ, Skjærven R. Survival and reproduction among males with birth defects and risk of recurrence in their children. JAMA 2001; 285: 755-760.

49. Nilsen ST. Boys born by forceps and vacuum extraction examined at 18 years of age. Acta Obstet Gynecol Scand 1984; 63: 549-554.

50. Nilsen ST, Bergsjø P. Males born in breech presentation 18 years after birth. Acta Obstet Gynecol Scand 1985; 64: 323-325.

51. Vatten LJ, Nilsen TIL, Tretli S, Trichopoulos D, Romundstad PR. Kroppsstørrelse ved fødsel og brystkreftrisiko i voksen alder: En prospektiv befolkningsundersøkelse. Norsk Epidemiologi 2005; 15 (1): 15-19.

52. Nilsen TIL, Romundstad P, Troisi R, Vatten LJ. Perinatale risikofaktorer for prostatakreft: En prospektiv populasjonsbasert studie. Norsk Epidemiologi 2005; 15 (1): 11-14. (Oversatt og lettere omarbeidet fra Int $J$ Cancer 2005; 113: 1002-1004).

53. Skjærven R. Dependencies in perinatal outcome between successive siblings. Influences on traditional measures in perinatal epidemiology assessed on the basis of births in Norway, 1967 1984. Avhandling. Bergen: Universitetet i Bergen, 1989.

54. Melve KK. Pregnancy outcome and family data: heterogeneity of risk, and sibling dependencies. Epidemiological studies of births in Norway, 1967-1998. Avhandling. Bergen: Universitetet i Bergen, 2003.

55 Skjærven R, Melve KK. Selective fertility - the examples of perinatal death and preeclampsia. Norsk Epidemiologi 2007; 17 (2): 175-180.

56. Skjærven R, Wilcox AJ, Russel D. Birthweight and perinatal mortality of second births conditional on weight of the first. Int J Epidemiol 1988; 17: 830-838.

57. Cappelen I, Lyshol H. Oversikt over helseregistre i Norge. Norsk Epidemiologi 2004; 14 (1): 33-38. 